\title{
Dynamics of Long-lived Foundation Species: The History of Quercus in Southern Scandinavia
}

\section{Citation}

Lindbladh, Matts, and David R. Foster. 2010. Dynamics of long-lived foundation species: The history of Quercus in southern Scandinavia. Journal of Ecology 98(6): 1330-1345.

\section{Published Version}

doi:10.1111/j.1365-2745.2010.01733.x

\section{Permanent link}

http://nrs.harvard.edu/urn-3:HUL.InstRepos:13056159

\section{Terms of Use}

This article was downloaded from Harvard University's DASH repository, and is made available under the terms and conditions applicable to Other Posted Material, as set forth at http:// nrs.harvard.edu/urn-3:HUL.InstRepos:dash.current.terms-of-use\#LAA

\section{Share Your Story}

The Harvard community has made this article openly available.

Please share how this access benefits you. Submit a story.

\section{Accessibility}


2 Dynamics of long-lived foundation species: the history of Quercus in 3 southern Scandinavia

4

5

6

$7 \quad{ }^{1}$ Southern Swedish Forest Research Centre

8 SLU - Swedish University of Agricultural Sciences

9 PO Box 49, 23053 Alnarp

10 Sweden

11 matts.lindbladh@ess.slu.se

12 Fax: +4640462325

13

$14{ }^{2}$ Harvard University

15 Harvard Forest

16324 North Main Street

17 Petersham, MA 01366

18 USA

19

20 Running title: The history of Quercus in Southern Scandinavia

21

22 Key-words: Denmark, extinction debt, forest conservation, forest history, land-use history, 23 oak, paleoecology, pollen analysis, Quercus robur, Sweden. 


\section{Summary}

1. The long-term history of Quercus in southern Scandinavia has received little attention despite its important role in modern conservation. In this study the 4000-year dynamics of Quercus, its habitat and other important taxa were analysed with pollen data from 25 small hollows and 6 regional sites across southern Scandinavia. The aim was to provide a context for understanding the species' current status and managing its future dynamics.

2. The results indicate that Quercus is much less abundant today than an any time during the previous 4000 years and corroborate the rapid decline reported in $18^{\text {th }}$ - and $19^{\text {th }}$. century historical records. Modern pollen percentages are $45-60 \%$ of $17^{\text {th }}$-century values and only $20-35 \%$ of the maximum values reached in the $3^{\text {rd }}$ century.

3. A strong positive correlation exists between the abundance of Quercus and the abundance of Tilia, Corylus and Alnus, which also experienced a steady decline across the region in the last two millennia. Climate change is the broad-scale driver of the observed dynamics, but human activity introduced considerable variation in the regional and temporal details of these changes. In the hemiboreal northern part of the study area the decline of Quercus appears to be controlled largely by competition with other tree species (especially Pinus and Picea), mediated by harvesting. In the temperate south part Quercus forests decreased through deforestation for agriculture.

4. Multivariate analyses indicate that although substantial phytogeographical variation has existed through past millennia the regional vegetation is more homogeneous today than in earlier periods. 
5. Synthesis. The long-term decline and recent rapid reductions in Quercus populations throughout southern Scandinavia are striking and indisputable. From the perspective of both the populations of Quercus and its associated species of insects and epiphytes, the recent rate of decline is extremely rapid. Given the former abundance, longevity and capacity for persistence of Quercus, current populations of Quercus and its associated species appear to represent biological legacies in the midst of protracted decline. Based on these results, a reasonable conservation goal is to restore the abundance and distribution of Quercus to levels that preceded the drastic decline in the $18^{\text {th }}$ and $19^{\text {th }}$ centuries.

\section{Introduction}

Across southern Scandinavia only a few trees qualify as foundation species, i.e. species that exert an impact on community and ecosystem properties greatly disproportionate to their abundance (sensu Dayton 1972; Ellison et al. 2005). Two of these, Fagus sylvatica (European beech) and Picea abies (Norway spruce), are shade-tolerant species whose historical roles have been extensively investigated with regards to abundance and distribution (e.g. Iversen 1973; Huntley et al. 1989; Björkman 1996a; Giesecke 2004; Bradshaw \& Lindbladh 2005; Seppä et al. 2009). In contrast, Quercus spp. (Oaks) include moderately shade-tolerant species (Q. robur and Q. petraea) that have received considerably less historical study despite their critical role in modern conservation. In spite of its scattered abundance in southern

Scandinavia, the importance of the genus Quercus for Swedish and European biodiversity is difficult to overstate (Ranius et al. 2005). Quercus provides critical habitat for lichens and fungi (Ranius \& Jansson 2000; Berg et al. 2002; Gärdenfors 2005) and represents the most important tree genus for red-listed invertebrates (Jonsell et al. 1998). 
75 Many characteristics of Quercus in the Swedish landscape provide challenges for conservation management. These include its low abundance and vulnerability to further reductions, its scattered distribution and the extreme age of many individuals. In particular, there is uncertainty concerning the future status of Quercus, the resulting consequences for species that are dependent on Quercus, appropriate targets for the restoration of populations in the landscape, and the need for management to achieve these desired conditions (Ranius 2000; Hedin 2003; Nordén et al. 2007; Økland et al. 2008; Tyler 2008). Some researchers have argued that conservation projections for the many rare insect and cryptogam species associated with Quercus are overly optimistic as they are based on persistence probabilities that do not appropriately account for long-term declines in Quercus and its associated habitats (Nilsson et al. 2005; Ranius et al. 2008). In their perspective, Quercus populations may be too scarce and fragmented to facilitate persistence and gene flow of rare species, which consequently exist under an 'extinction debt' (sensu Tilman et al. 1994; Hanski et al. 1996).

To address these concerns and to examine the potential for future declines and extinction, studies have attempted to place the recent dynamics and status of Quercus in a historical context based on early $19^{\text {th }}$-century data (Hedin 2003; Ranius et al. 2004). However, effective evaluation of long-lived trees like Quercus, which produce biological legacies (sensu Lindenmayer \& Franklin 2002) and habitats that may endure for many centuries, require an even longer time-perspective. Quercus frequently live 300 years in closed forests, 400-600 years in open woodlands and pastures and as much as c. 1000 years under optimal conditions (Niklasson \& Nilsson 2005; Drobyshev et al. 2008). Furthermore, the coarse dead wood of Quercus may provide an important substrate for other taxa, especially insects, fungi and microbes, which endure over many hundreds of years. To provide insights into these critical 

Quercus abundance during the last 4000 years. To enhance the conservation insights

ecological and conservation issues it is necessary to develop a regional reconstruction by employing an approach that combines the time-depth of paleoecology and the stand to landscape-scale spatial resolution of field sampling. The appropriate paleoecological approach for this effort combines the analysis of a network of small hollows, which yield local information, with the regional-scale record provided through the analysis of lake sediments (cf. Jacobson \& Bradshaw 1981; Foster \& Zebryk 1990).

In our investigation of the ancient and recent history of Quercus we analysed the pollen data from 25 small hollow sites across southern Scandinavia (Fig. 1, Table 1). Small hollows act as local pollen collectors and yield stand to landscape-level information on vegetation composition and dynamics as well as natural and anthropogenic disturbances (Bradshaw 2007). In appropriate settings they may accumulate continuous sediment records spanning centuries to millennia and can therefore be regarded as analogous to extremely long-term permanent plots (sensu Jacobson \& Bradshaw 1981). High-resolution records from a regional network of small hollows may then be analysed through GIS and multivariate statistics to provide a regional perspective that resolves the geographical detail and variation among vegetation zones, across major edaphic and environmental gradients or even among different land-uses in a single estate.

To augment and contrast the local to regional understanding emerging from the network of hollows we analysed the independent record of regional-scale vegetation dynamics provided by pollen analyses of sediment cores from six lakes distributed across the study region. In both sets of reconstructions we focused on interpreting the dynamics and drivers of changes in emerging from prior historical studies, we placed special emphasis on the $18^{\text {th }}$ and $19^{\text {th }}$ 
centuries, seeking to: evaluate the accuracy of the reconstructions of declines coming from

125 historical records, provide additional insights into the dynamics of Quercus preceding this

126 fairly well documented period, and contrast these recent dynamics with those from previous

127 millennia.

\section{Material and methods}

130

\section{Regional history of Quercus in southern Scandinavia}

132 Numerous pollen records and historical sources provide the history of regional forest

133 dynamics that are useful for interpreting the spatially resolved patterns of change emerging

134 from small hollows over the past few millennia. Records from lake sediments indicate that

135 Quercus abundance peaked across southern Scandinavia through the thermal maximum 9000

136 to 6000 years ago (Iversen 1973; Berglund et al. 1996; Rasmussen 2005). However, from a

137 maximum of $>20 \%$ of pollen in the mid Holocene Quercus declined substantially in most

138 records (Fig. 2 and 3; Björse et al. 1996; Berglund et al. 2007). Written sources suggest a

139 more recent decline over the past hundreds of years. An important timber for warships,

140 Quercus was declared to be the property of the Swedish state by King Gustav Vasa in AD

141 1558. At the end of the $18^{\text {th }}$ century the increasing population of more self-assured peasants

142 successfully applied pressure on the state to allow access to Quercus trees, leading to an

143 increase in harvesting (Eliasson 2002). According to subsequent state inventories from 1790

144 to 1825 the abundance of Quercus trees that met naval standards decreased by more than $80 \%$

145 across southern Sweden. Most of the decline appears to have occurred in meadows and arable

146 lands close to villages (Eliasson \& Nilsson 2002). Royal ownership of Quercus officially

147 ended in 1830, which resulted in a further increase in harvesting by peasants, and a

148 corresponding decline in useful trees (Eliasson \& Nilsson 2002; Hedin 2003). In Denmark a 
149 general decline in forest cover also occurred from the $16^{\text {th }}$ century onwards. In particular,

150 during the period AD 1650-1750, and associated with an expansion of agricultural activities

151 by an increasing human population, many forests of mature Quercus and Fagus were

152 converted into dense brushwood (Fritzbøger 1992). The landlords and the Crown foresters

153 decried the loss of timber trees whereas peasants readily used the brushwood for coppice and

154 grazing. In remaining forests Fagus gradually became dominant. The $18^{\text {th }}$ century

155 assessments contain little evidence of mature Quercus trees.

156

157 Study object

158 Two species of Quercus occur in the region today: Q. robur (Pedunculate oak) and Q. petraea

159 (Sessile oak). Quercus robur occurs throughout the temperate (nemoral) region and is one of

160 the most widely distributed trees in Europe. It is a relatively light-demanding species that

161 regenerates poorly under a closed canopy (Diekmann 1996; Vera 2000). It has a large site

162 amplitude but is most competitive on dry and wet sites with low fertility where Fagus

163 sylvatica grows less vigorously (Larsen et al. 2005). On fertile sites and in the absence of

164 large-scale disturbance, $Q$. robur is also generally less competitive than Ulmus (Elm), Tilia

165 (Linden), Fraxinus (Ash) and Acer (Maple) (Niklasson \& Nilsson 2005). Historically it was

166 probably rather tolerant to fires and also favoured by human activity (Bradshaw \& Lindbladh

167 2005). Quercus petraea has a similar distribution and ecology as Q. robur but is much less

168 common. Compared to Q. robur it has an even larger tolerance to sites with thin soils but is

169 less tolerant of poorly drained conditions.

170

171 In Scandinavia Quercus has a southern distribution, centred along the coast in the temperate

172 vegetation zone (Fig. 2). In this region a large proportion of the remaining forest is comprised

173 of broadleaf trees but the total forest area is rather limited $(<30 \%)$ due to historical conversion 
174 to arable land and residential and commercial development. In the more northern hemiboreal

175 zone approximately $60 \%$ of the land is occupied by forests, but Quercus occurs as a minor

176 component. Forests in this region are largely dominated by nearly pure stands of Picea abies

177 (c. $47 \%$ of total volume) and Pinus sylvestris (ca 29\%) managed for timber production and

178 characterized by low value for biodiversity. Quercus occurs both in natural stands and in

179 forests intensively managed for timber production. Approximately one-third of the trees

180 exceed $45 \mathrm{~cm}$ in diameter, with most of the larger trees occurring in natural stands (Nilsson et

181 al. 2008). Quercus intended for timber production are usually cut by an age of c. 120 years,

182 which is decades before they develop the 'old tree structures' of large stem diameter, coarse

183 cracked bark and decay-infested hollows that provide important habitats for many insects and

184 epiphytes species (Berg et al. 1994; Nilsson \& Niklasson 2005). A large proportion of the

185 remaining older coarse trees grow in the former infields of estates (Eliasson \& Nilsson 2002).

186 Historically, estates were separated into infield (Swedish inäga) and outland (Swedish

187 utmark), a division that persisted in large parts of southern Scandinavia for many hundred

188 years until the early $20^{\text {th }}$ century. Generally, infields lay closer to the village buildings and

189 contained arable land and hay meadows, whereas outlands were largely forested and primarily

190 used for grazing.

191

192 Site selection and regional variation

193 With one exception all sites investigated for local records are small hollows or wetlands

194 selected from previous studies (Table 1, Fig. 1). The additional site is Hälledammen, a c. 50-

195 m diameter pond located on an island off the west coast of Sweden. The sites fall equally into

196 the temperate (13 sites) and hemiboreal (12 sites) zones (cf. Ahti et al. 1968), which differ in

197 vegetation, climate and physiography. The border between the zones corresponds largely to

198 the historic border between Sweden and Denmark that persisted until AD 1658. Before 
extensive modern forestry the temperate zone was dominated by broad-leaved species

200 (Quercus, Tilia, Fagus) whereas the hemiboreal zone was a transition zone comprised of both temperate and boreal trees (Pinus, Picea, Betula) and greater evergreen cover. The hemiboreal zone is slightly higher in elevation, has colder winters and is dominated by granite or gneiss bedrock in contrast to more fertile sedimentary bedrock in large parts of the temperate zone (Wastenson 1990). Across the study region seventeen sites could be designated to a land-use practice: twelve in former outlands and five in former infields.

Regional pollen diagrams were obtained from the European Pollen Database, three from each vegetation zone (Fig. 1). These include Lake Trummen and Lake Växjösjön (Digerfeldt 1972; 1977), Ranviken (Digerfeldt 1973), Lake Kansjön (H. Jacobson unpublished), Ageröds mosse

210 (Nilsson 1964), Lake Krageholmssjön (Gaillard 1984) and Lake Färskesjön (Berglund 1966).

211 Because the upper sediments of Lake Trummen are missing (Digerfeldt, 1972), we used the 212 pollen records from the adjacent Lake Växjösjön (Digerfeldt, 1977) for the last 1200 years.

213 The records cover the last 4000 years and are geographically representative of the region. The 214 pollen records from large sites are assumed to represent the regional vegetation at a scale of 215 ca. $100 \times 100 \mathrm{~km}$ around each lake (Hellman et al. 2009b).

\section{Data handling, pollen source area and statistics}

218 For all analyses of the pollen data, percentage values were employed rather than PAR (Pollen 219 Accumulation Rates) as PARs were available for only 14 of the small hollow sites. Due to the

220 large number of pollen analysts and varying taxonomic detail in the studies as well as the 221 central focus on Quercus, we chose to focus on common taxa represented by at least 5\% in 222 one or more samples. Cyperaceae was excluded due to its frequent abundance in wetlands. 223 Human land use was inferred from the relative abundance of Cerealia and the combined 
abundance of four easily identified and robust indicators of agricultural activities: Rumex acetosa, R. acetosella, Artemisia, Plantago lanceolata and Polygnum aviculare (Gaillard 2007). For comparison and statistical analysis, the pollen records were divided into 200 -year and 100-year periods before and after $\mathrm{AD} 0$, respectively. These period lengths represent a compromise between resolution and accuracy. For periods lacking samples (c. $20 \%$ in both zones) values were interpolated as the mean of the two adjacent periods. Maps of pollen 230 values for each local site were developed for five periods: 200-399 BC and AD 200-299, 900$231999,1600-1699$ and 1900-1999. Summary diagrams of the mean pollen percentages from the small sites for the major taxa were constructed for each of the vegetation zones as a mean to compare the development of the regional vegetation between the temperate and the

234 hemiboreal zones. The percentages vary greatly among the small-hollow sites, which 235 corroborates the expectation that each site records pollen from a restricted source area within 236 a given landscape (Sugita 1994). Based on simulated and empirical relation between pollen 237 and vegetation in the south Swedish vegetation/landscape setting of the last 6000 years, the 238 relevant source area (RSAP) of small sites (bogs and lakes) is estimated to be between c. 1000 239 and $2000 \mathrm{~m}$ in radius (Hellman et al. 2009a; Hellman et al. 2009b). However, we believe the 240 mean value from each vegetation zone is a reasonable approximation for the regional 241 development. The mean values for each zone remained consistent over time, exhibiting only 242 small fluctuations between adjacent levels. The overall trends appear broadly representative 243 and for most taxa the sites in a region display a similar pattern of change through time. Our 244 assumption is furthermore supported by a quantitative modelling approach for vegetation 245 reconstruction by Sugita (2007), which suggests that mean values from many small sites is a 246 good estimator for the regional vegetation composition. 
Spearman's partial correlation was used to examine the relationship between Quercus, other

249 taxa and the anthropogenic indicators the last 1800 years. To adjust for the effect of site, zero-

250 one variables were used as partialized variables for the sites. Ordination by non-metric

251 multidimensional scaling (NMS; PCord 5.10 software) employing Sorensen's relative

252 distance was used to display the vegetation relationships among sites at four of the mapped

253 time periods: AD 200-299, 900-999, 1600-1699 and 1900-1999. Non-metric

254 multidimensional scaling (NMS) was used because it performs well with non-normal data like

255 pollen percentages (Clarke 1993; Quinn \& Keough 2002) and Sorenson's relative distance is

256 broadly effective with ecological data (Faith et al.1987). The calculations compared one- to

257 six-dimensional solutions using the NMS autopilot in the 'slow and thorough' mode, where

258 the program follows a predefined template (McCune \& Mefford 1999).

260 The vegetation reconstructions were evaluated in relation to the Northern Hemisphere

261 temperatures for the past 2000 years developed by combining low-resolution lake and ocean

262 sediment proxies with tree-ring data (Moberg et al. 2005).

\section{Results}

266 The regional dynamics of Quercus and comparison between the hemiboreal and temperate

267 zones are displayed in the mean pollen values from the 25 small hollow sites and the

268 percentage values from the regional sites (Fig. 3). Small hollow values for Quercus from

269 1000-0 BC were $25-30 \%$ in the temperate zone and $12-14 \%$ in the hemiboreal zone. Quercus

270 increased in both zones shortly after AD 0 and peaked around AD 100-400 in the temperate

271 zone and AD 200 in the hemiboreal zone. Subsequently, Quercus decreased steadily in both

272 zones, although exhibiting more stability from AD 1100 to 1600 in the temperate zone. 
273 Quercus showed a marked decrease in both zones in the $18^{\text {th }}$ century and has had persistently 274 low values through the last 300 years. A small increase occurred in the $20^{\text {th }}$ century. The 275 regional sites exhibit parallel records of declining percentages of Quercus over the last 2000 276 years. Overall, however, both the initial values and the magnitude of the declines were less in 277 the lake than the small hollow sites. In the regional records pollen values for Quercus were c. $27810 \%$ at $\mathrm{AD} 0$ and decreased slowly to between 2 and $8 \%$ in the last century.

The vegetation exhibited strong regional patterns with Tilia, Fagus, Poaceae and anthropogenic indicators at higher values in the temperate zone than in the hemiboreal zone and Pinus, Picea and Calluna were more abundant in the hemiboreal zone (Fig. 4). Most taxa exhibited a significant relationship to Quercus through the period of Quercus decline over the

284 last 1800 years (Table 2). Quercus was positively correlated with variations in Tilia and 285 Corylus and less strongly to Alnus in the temperate zone and strongly with Corylus, Tilia and 286 Alnus in the hemiboreal zone. Strong negative correlations occurred with Cerealia, Picea and 287 Fagus in the temperate and Pinus and Picea in the hemiboreal zone. In the hemiboreal zone 288 Quercus had no significant relationship to Fagus.

Pollen maps for the major taxa display the spatial patterns in vegetation over the last 2300

291 years (Fig. 5). Quercus was rather frequent and abundant ( $\geq 10 \%$ at most sites) until the $17^{\text {th }}$

292 century, but somewhat less abundant in northern and north-eastern sites. It declined towards

293 the $17^{\text {th }}$ century but remained common around some sites in the south-central part of the 294 hemiboreal zone where its abundance is low today (Fig. 2 and 5). The development of the 295 modern pattern, with Quercus common only at a few sites, became apparent only in the pollen 296 map from the $20^{\text {th }}$ century. Pinus was initially common only along the east coast, but 297 increased dramatically at most northern sites from the $17^{\text {th }}$ and $20^{\text {th }}$ centuries. Alnus decreased 
regionally in the last centuries, especially in the south. Corylus and Tilia have consistently

299 decreasing values across the region through time. Taking into account the low productivity 300 and dispersal of its pollen, Tilia appears to have been abundant into the $10^{\text {th }}$ century and to

301 have remained relatively abundant around some northern sites longer than at southern sites.

302 Fagus and Picea exhibited increasing values through time. Fagus expanded over the last 1000

303 years predominantly in the south. The expansion of Picea occurred over the last few hundreds

304 of years in northern sites. Cerealia were recorded throughout the last two millennia but 305 display maximum values in the $17^{\text {th }}$ century when they are recorded at most sites. A similar 306 pattern is seen in the anthropogenic indicators, which were present in all periods, but became 307 somewhat more frequent during the last two hundred years.

309 The limited number of infield sites constrains the comparison with outfield sites to the period 310 from AD 300 onward (Fig. 6). The mean Quercus value from outland sites decreased from 25 311 to $15 \%$ between $\mathrm{AD} 300$ and $\mathrm{AD} 1100$. The percentage then dropped drastically over the past 312 centuries to $2-3 \%$. Mean values for infield sites were lower except at the very end of the 313 record. Initially around 10\%, they peaked at c. 13\% around AD 800-1000 and then dropped 314 steadily after that.

316 In the NMS analysis of the 14 taxa, 25 sites and 96 levels the final stress was $9.8 \%$, which 317 differs significantly $(\mathrm{p}<0.01)$ from the randomized Monte Carlo tests. Axis scores were $\mathrm{r}^{2}=$ $3180.38,0.33$ and 0.22 for axis 1, 2, and 3, respectively. The boreal taxa Picea, Pinus and 319 Calluna were grouped in the upper right in the diagram (Fig. 7). Betula was close to these taxa, but had lower scores on axis 1 . The anthropogenic indicators, Cerealia and Poaceae were 321 grouped together with weakly negative scores on both axes. The temperate taxa Tilia and 
Corylus were located together with Alnus in the lower part of the diagram. Quercus and

323 Fagus were both in the lower left.

325 In the NMS diagram from AD 200-299 most temperate sites were located close to Quercus,

326 Tilia and Corylus, whereas the hemiboreal sites were more evenly spread out in the diagram

327 (Fig. 8). Overtime there was a tendency for more central clustering of all sites (less variation),

328 a separation of hemiboreal and temperate sites, and a strong clustering of hemiboreal sites in

329 the upper right, close to the boreal taxa. The distinction between the two regions emerged

330 around AD 900-999 and was greatest from AD 1600-1699. At AD 1900-1999 there was a

331 clear break between the hemiboreal sites and many temperate sites. However, most temperate

332 sites overlapped strongly with the hemiboreal sites due to the stronger influence of boreal

333 taxa. Hence, during the last century there was a separation among temperate sites and a shift

334 from the previous historical location and composition of temperate sites earlier in time.

Discussion

Long-term dynamics of Quercus and other tree taxa

339 The relative decrease of Quercus pollen as recorded in the small hollows was greatest in both 340 vegetation zones between the $17^{\text {th }}$ and $19^{\text {th }}$ century (Figs. 3 and 5). These results confirm the 341 reports of rapid decline of Quercus in $18^{\text {th }}$ - and $19^{\text {th }}$-century historical records and place it into 342 the context of much longer-term dynamics (Eliasson 2002; Eliasson \& Nilsson 2002; Hedin 343 2003). Specifically, it is clear that the genus is much less abundant today than an any time 344 during the previous 4000 years. In the hemiboreal zone modern pollen percentages are less 345 than $45 \%$ of the values observed at AD 1600 and c. $20 \%$ of the maximum values reached in 346 AD 200. The decline is somewhat less but nonetheless striking in the temperate zone, where 
347 the modern values are $60 \%$ and $35 \%$, respectively, of the pre-historical values. The rapid and

348 recent reductions of Quercus documented in historical records and the small hollows are more

349 subtle in the regional pollen diagrams (Fig. 3; Regnell 1989; Thelaus 1989; Rasmussen 2005).

350 The regional records often have low temporal resolution in recent centuries where changes in

351 arboreal pollen are abrupt and frequently obscured by major increases in non-arboreal taxa.

352 The low absolute abundance of Quercus is also obscured on many forest maps as these

353 frequently represent species in terms of percentages of forest growing stock and may

354 consequently represent Quercus as a dominant species in largely deforested landscapes such

355 as the coastal region (Fig. 2).

357 At the landscape scale there is a strong indication that the abundance and dynamics of

358 Quercus populations varied across areas of different land-use (Fig. 6). Our data do not support

359 the interpretation that Quercus was often more abundant in infields (arable land and

360 hayfields) as a consequence of active management to protect this species (Eliasson \& Nilsson

3612002 and references therein). Although our sample of infield sites is small and should be

362 interpreted with caution, the opposite trend is suggested at many sites. When our data allows

363 for direct comparison (infields and outlands cored on the same estate), Quercus pollen

364 percentages were comparable on infields and outlands (Råshult infield and outland -

365 Lindbladh \& Bradshaw 1998; Osaby infield and outland - Lindbladh 1999). One possible

366 explanation for the discrepancy between the historical and pollen records is that historical

367 inventories may have been biased towards the immediate vicinities of estates and villages and

368 thereby overemphasized Quercus populations in those areas. A second possibility is that the

369 historical sources accurately portray differences in large and valuable trees. Naval and other

370 inventories were predominantly focused on large merchantable trees that were useful for

371 construction of ships or buildings, whereas pollen records represent the relative abundance 
and flowering of all sizes and qualities of trees. While larger trees may have been more

373 abundant in the infields, the overall abundance of Quercus may have differed little across the

374 landscape. Such variation in the distribution of larger and presumably older trees would be

375 relevant from a conservation perspective, however, as the older trees were the carrier of many

376 of today's rare species (Berg et al. 1994; Nilsson et al. 2002).

377

378 The strong positive correlation between Quercus and Tilia, Corylus and Alnus and the consistent steady decline of these taxa across southern Scandinavia during the last two millennia (Table 2; Fig. 4) suggests that climate change is the broad-scale driver of the observed dynamics (Huntley \& Webb 1989; Pearson \& Dawson 2003). However, the longterm decline of Quercus was consistent throughout the last 2000 years and no simple relationship occurs between this trajectory and changes in temperature, for instance through the warm early Middle Age or the comparatively cool Little Ice Age (Fig. 4). Our records do indicate that human activity induced complexities in both the regional variation and temporal details of these long-term dynamics. The initial decline of the thermophilous taxa, Tilia and Corylus, c. 4000 years ago in Southern Scandinavia is most likely related to a decrease in temperature (Hammarlund et al. 2003; Seppä et al. 2005). Quercus and Alnus do not begin to decline until c. 2000 years ago, presumably in response to a further decrease in temperature (Seppä et al. 2005) and only after Quercus reaches a peak across the region (Fig. 4). Quercus is less shade-tolerant than Tilia and other temperate deciduous species (Diekmann 1996; Larsen et al. 2005), and may have been favoured by the increasingly open pastoral landscape initiated during the Bronze age (c. 1500-500 BC), particularly in the temperate zone (Berglund et al. 1991). Open conditions through this period are indicated by an increasing value of Poaceae and the low, but constant, record of anthropogenic indicators. The only Alnus species in the region today, Alnus glutinosa, occupies moist sites and is represented 
with high values in our local diagrams from wetland sites in contrast to many regional lake records (e.g. Gaillard 1984; Digerfeldt 1972). Although the dynamics of Alnus should reflect both the gradual decline in temperature and availability of suitable moist conditions generated by broad-scale climate change during the past 4000 years (Tallantire 1974; Larsen et al. 2005; Seppä et al. 2005), it is likely that the long-term decline in this species also reflects the gradual clearing of the landscape of trees and conversion of wet forests into open meadows (Berglund et al. 1991).

\section{Drivers of long-term vegetation dynamics}

The landscape-scale resolution of our pollen records provides insights into the details of the Quercus decline and the species and vegetation that replaced it. In the hemiboreal zone the decline of Quercus appears to be controlled by competition with other forest species, mediated by human activity. Picea and Pinus are strongly negatively associated with Quercus and increase as it declines (Table 2). Pinus was common in the eastern hemiboreal zone in the beginning of our record (Fig. 5). On a landscape scale it is likely that Pinus replaced Quercus in the hemiboreal zone due to the strong similarities of the two species in terms of fire resistance and tolerance for both dry and wet sites (Table 2; Sykes et al. 1996; Larsen et al. 2005; Bradshaw \& Lindbladh 2005). Indeed, as Pinus became more common in the west after AD 900, there was a notable decline in Quercus (Fig. 5).

Picea entered the region from the north c. 1000 years ago. From there it spread south and east probably in response to colder and snowier conditions (Fig. 5; Bradshaw et al. 2000; Giesecke \& Bennett 2004; Bradshaw \& Lindbladh 2005), although the exact role of climate in this migration is not completely clear (Miller et al. 2008). Picea is a strong competitor with shadetolerant temperate species (Seppä et al. 2009) and it is therefore likely that the decline of 
445 Fire has been suggested as an important factor in controlling the historical abundance of 446 Quercus (Niklasson et al. 2002; Greisman \& Gaillard 2009). Although not explicitly

Quercus at many sites in the hemiboreal zone was due to competition with Picea. Although anthropogenic indicators are rather unimportant in the hemiboreal zone, it appears that selective cutting may have been a factor leading to a decline in Quercus and facilitating the initial entry of Pinus and Picea into forested sites. Such a development is described at the end of the $19^{\text {th }}$ century when Picea entered into the area of its southernmost distribution in Sweden today (Hesselman \& Schotte 1906). The increasing number of domestic animals and intense grazing when agriculture expanded during the mediaeval colonization (Lagerås 2007) likely promoted the decline of Quercus relative to the conifers and temperate deciduous trees that are more resistant to grazing (Götmark et al. 2005). The apparent persistence of Quercus at higher abundances on outlands until its decline c. 300 years ago may be due to its tolerance for unfertile, dry and moist sites (Fig. 6; Diekmann 1996).

In contrast to the hemiboreal zone, in the temperate zone Quercus forests were likely replaced by agriculture. Here, as in the hemiboreal zone, Quercus declined after its peak around 200$400 \mathrm{AD}$, but coincident with a much greater increase of anthropogenic indicators (Table 2; Fig. 4 and 5). While both Cerealia and anthropogenic indicators are low in abundance and show weak negative correlations with Quercus in the hemiboreal zone, in the temperate vegetation zone Cerealia are more prominent and more strongly negatively correlated to Quercus. It appears that in the south and west agricultural land began to replace Quercus in many places after the $5^{\text {th }}$ century $\mathrm{AD}$. In both zones modern forestry and regional planting produced the large regional increase of the two conifers during the last c. 150 years (Fig. 5; Hesselman \& Schotte 1906).

$$
\text { Fre has been suggested as an important factor in controlling the historical abundance of }
$$


addressed in this study, forest fires were historically common in the hemiboreal zone until the

448 mid $18^{\text {th }}$ century (Niklasson \& Drakenberg 2001; Bradshaw \& Lindbladh 2005). Fire

449 suppression in Sweden over the course of the last centuries is believed to have reduced

450 Quercus regeneration (Niklasson et al. 2002; Lindbladh et al. 2003). However, a recent study

451 examining charcoal and pollen in the same region as this study found only a weak negative

452 correlation between charcoal and Quercus pollen abundance (Bradshaw et al. in press).

453

454 Regional pattern of vegetation change

455 Ordination of the pollen data across the range of sites through time demonstrates major

456 changes in the regional pattern of vegetation variation (Fig. 7). Although the sites exhibit

457 regional variation today, at AD 200-299 temperate and hemiboreal sites were rather evenly

458 mixed in the diagram. At that time many sites were strongly dominated by temperate taxa and

459 Alnus, and geographical variation was weakly expressed. The separation of sites into

460 distinctive geographical groupings begins at AD 900-999 as sites from the two zones start to

461 separate. This process continues through to AD 1900-1999 when many of the temperate sites

462 have higher scores on both axes, indicating a shift from temperate conditions at AD 200-299

463 to more hemiboreal conditions. However, since AD 200-299 the overall spread of site scores

464 and the apparent variation in vegetation has declined across all sites and between the

465 vegetation zones. Thus, while regional patterns emerged and persisted, the regional vegetation

466 as a whole has become more homogenous, as reflected by the ordination, compared to

467 previous periods. Much of this modern increase in similarity among the sites in the different

468 zones is due to increased human impacts, in particular the widespread introduction of conifer

469 forests in southern Sweden (Kardell 2004; Niklasson \& Nilsson 2005). A similar

470 homogenization of regional vegetation patterns can be seen in forests across the north-eastern 
United States as a consequence of similarities in broad-scale land use activities (Foster et al. 1998; Oswald et al. 2008).

\section{Implications for conservation}

This study provides a lengthy perspective for conservation management and insights into Quercus forests across the region. The long-term decline and recent rapid drop in Quercus populations throughout southern Scandinavia is striking and indisputable. While these results pertain to Quercus populations alone and not the many threatened species associated with Quercus, it is clear that this foundation taxon has undergone a major shift in abundance and distribution as a consequence of both broad-scale and local factors. Millennium-scale climatic change is a major factor driving the long-term decline of Quercus and changing abundance relative to other important tree taxa. However, the details of this decline, the late date (last 200-300 years) relative to other thermophilic tree species, and the close correlation between Quercus and numerous anthropogenic indicators underscores the important role of recent human activities.

\section{From the perspective of both the populations of Quercus and its associated species of insects} and epiphytes, the rate of decline is extremely rapid. For this long-lived tree the last millennium represents no more than two to three generations. Meanwhile, studies of the rare Hermit beetle (Osmoderma eremita) demonstrate that individuals of this species have extremely restricted dispersal, perhaps only a couple of hundred meters. As a consequence a Quercus stand can host a metapopulation of this beetle for several centuries (Hedin 2003; Ranius \& Hedin 2004). Given the former abundance of Quercus, the tree species longevity, and the capability for persistence, it is likely that our current populations of Quercus and its 
associated species represent legacies of former conditions in a process of slow and spiralling

496 decline that could lead to disappearance.

498 In order to reverse this trajectory it appears critical to re-establish Quercus population 499 abundance and distribution to levels that existed in prior times and as documented in this 500 study. To enhance population survival and facilitate dispersal among populations and in the 501 face of future environmental changes, it is advisable to increase Quercus populations and establish increased connectivity among Quercus forests across the landscape and region. This activity should not only focus on infield sites (or on areas in their proximity) that represent conservation hotspots in the modern landscape (Nilsson 2001), but be applied also across the broader landscape and through the matrix of today's production forest. Quercus naturally regenerate in not too dense coniferous production forests, especially in dry and warm areas, and if the browsing pressure is not too strong (Götmark et al. 2005). The natural regeneration will probably increase under a warmer future climate (Sykes et al. 1996). However, today's management regime overrides climate in controlling the abundance of the species. Current

510 practices in coniferous production stands call for a total removal of all Quercus saplings 511 during pre-commercial thinning (Götmark et al. 2009).

As for future levels of Quercus, the taxon's abundance before the drastic decline in the $18^{\text {th }}$

514 and $19^{\text {th }}$ centuries would appear to provide a reasonable target. At that time many of the 515 current rare or extinct Quercus-associated species did still occur (Osbeck 1996; Ljungberg et $516 a l$. unpublished data). In order to reach this target which is biologically and historically 517 modest, but logistically and economically ambitious, it will be necessary to (i) identify and 518 implement the most cost-effective and efficient ways to regenerate and manage Quercus 519 forests (Madsen \& Löf 2005; Götmark 2007) and (ii) integrate the ongoing establishment and 
retention of biologically valuable Quercus into the management of conifer production forests (Koch Widerberg et al. unpublished data).

\section{Acknowledgements}

We are grateful to Jan-Erik Englund, Dan Hammarlund, Brian Hall, Emma Holmström and Adam Felton for assistance with the study and would like to thank many colleagues and students for contributing pollen data. A special thank to Richard Bradshaw for initiating the Small Hollow Database of southern Scandinavia. The study was funded through a Charles Bullard Fellowship at Harvard University and a Wenner-Gren Foundation sabbatical stipend to Matts Lindbladh.

\section{References}

Abrahamsson, Å. (1996) Pollenanalytisk studie i Ryfors Gammelskog, Vastergötland. MSc thesis. Lund University, Lund, Sweden.

Ahti, T., Hämet-Ahti, L. \& Jalas, J. (1968) Vegetation zones and their sections in northwestern Europe. Annales Botanica Fennica, 5, 169-211.

Berg Å., Ehnström B., Gustafsson L., Hallingbäck T., Jonsell M. \& Weslien J. (1994) Threatened plant, animal, and fungus species in Swedish forests: Distribution and habitat associations. Conservation Biology, 8, 718-731.

Berg, A., Gärdenfors, U., Hallingbäck, T. \& Norén, M. (2002) Habitat preferences of redlisted fungi and bryophytes in woodland key habitats in southern Sweden - Analyses of data from a national survey. Biodiversity and Conservation, 11, 1479-1503.

Berglund, B.E. (1966). Late-Quaternary vegetation in eastern Blekinge, south-eastern Sweden. Opera Botanica, 12, 3-180. 
Berglund, B.E., Malmer, N., Persson, T. (1991) Landscape-ecological aspects of long-term changes in the Ystad area. The Cultural Landscape During 6000 years in Southern Sweden — the Ystad Project. (ed Berglund, B.E.), Ecological Bulletins, 41, 405-424.

Berglund, B.E., Björkman, L., Holmqvist, B.H. \& Persson, T. (2007) Skånes vegetationshistoria - förändringar under 17000 år. Floran i Skåne: arterna och dess utbredning (ed T. Tyler), pp. 27-38. Lunds botaniska förening.

Berglund, B.E., Digerfeldt, G., Gaillard, M.-J., Engelmark, R., Karlsson, S., Risberg, J. and Miller, U. (1996). Palaeoecological Events During the last 15000 years (eds Berglund, B.E., Birks, H.J.B., Ralska-Jasiewiczowa, M., and Wright, H.E.). pp. 233-280., Wiley and Sons, New York.Björkman, L. (1996a) The Late Holocene history of beech Fagus sylvatica and Norway spruce Picea abies at stand scale in southern Sweden. Lundqua thesis Volume 39. Lund University, Lund

Björkman, L. (1996b) Long-term population dynamics of Fagus sylvatica at the northern limits of its distribution in southern Sweden: a palaeoecological study. The Holocene, 6 , $225-234$.

Björkman, L. (1997a) The history of Fagus forest in southwestern Sweden during the last 1500 years. The Holocene, 7, 419-32.

Björkman, L. (1997b) The role of human disturbance in the local Late Holocene establishment of Fagus and Picea forests at Flahult, western Småland, southern Sweden. Vegetation History and Archaeobotany, 6, 79-90.

Björkman, L. \& Bradshaw, R.H.W. (1996) The immigration of Fagus sylvatica L. and Picea abies (L.) Karst. into a natural forest stand in southern Sweden during the last two thousand years. Journal of Biogeography, 23, 235-244. 
Björse, G., Bradshaw, R.H.W. \& Michelson, D.B. (1996) Calibration of regional pollen data to construct maps of former forest types in southern Sweden. Journal of Paleolimnology, 16, 67-78.

Bradshaw, R.H.W (2007) Pollen methods and studies - Stand-Scale Palynology. "Encyclopedia of Quaternary Science” (ed S.A. Elias), pp. 2535-2543. Elsevier, Amsterdam.

Bradshaw, R.H.W., Hannon, G. \& Lindbladh, M. (In press) The role of fire in southern Scandinavian forests during the late Holocene. International Journal of Wildland Fire.

Bradshaw, R.H.W., Holmqvist, B.H., Cowling, S.A. \& Sykes, M.T. (2000) The effect of climate change on the distribution and management of Picea abies in southern Scandinavia. Canadian Journal of Forest Research, 30, 1992-1998.

Bradshaw, R.H.W. \& Lindbladh, M. (2005) Regional spread and stand-scale establishment of trees in North-West Europe. Ecology, 86, 1679-1686.

Clarke, K.R. (1993). Non-parametric multivariate analyses of changes in community structure. Australian Journal of Ecology, 18, 117-143.

Dayton, P.K. (1972) Toward and understanding of community resilience and the potential effects of enrichments to benthos at McMurdo Sound, Antarctica. Proceedings of the colloquium on conservation problems in Antarctica (ed B.C. Parker). Allen Press Lawrence, KS.

Diekmann, M. (1996) Ecological behaviour of deciduous hardwood trees in Boreo-nemoral Sweden in relation to light and soil conditions. Forest Ecology and Management, 86, 1-14. Digerfeldt, G. (1972) The post-glacial development of Lake Trummen. Folia Limnologica Scandinavica, No. 16, 1-104 CWK Gleerup, Lund. 
Digerfeldt, G. (1973). The post-glacial development of the bay Ranviken, Lake Immeln, I Regional vegetation history, II Water level changes. University of Lund Department of Quaternary Geology Report 1,1-59.

Digerfeldt, G. (1977) Palaeoecological Studies of the Recent Development of Lake Växjösjön. Archiv für Hydrobiologie, 79, 465-477.

Drobyshev, I., Niklasson, M., Linderson, H., Sonesson, K., Karlsson, M., Nilsson, S.G. \& Lanner, J. (2008) Lifespan and mortality of old oaks - combining empirical and modeling approaches to support their management in Southern Sweden. Annals of Forest Science, 65, 401.

Eliasson, P. (2002) Skog, makt och människor. Kungliga Skogs och lantbruksakademien. Skogs- och lantbrukshistoriska meddelande $n r$ 25. Stockholm (in Swedish with English summary).

Eliasson P. \& Nilsson S.G. (2002) You should hate young oaks and young Noblemen - The environmental history of oak in eighteenth- and nineteenth-century Sweden. Environmental History, 7, 659-677.

Ellison, A.M., Bank, M.S., Clinton, B.D., Colburn, E.A., Elliott, K., Ford, C.R., Foster, D.R., Kloeppel, B.D., Knoepp, J.D., Lovett, G.M., Mohan, J., Orwig, D.A., Rodenhouse, N.L. Sobczak, W.V., Stinson, K.A., Stone, J.K., Swan, C.M., Thompson, J., Von Holle, B. \& Webster, J.R. (2005) Loss of foundation species: Consequences for the structure and dynamics of forested ecosystems. Frontiers in Ecology and the Environment, 3, 479-486.

Eriksson, G. (1996) Skogshistoria, kulturpåverkan och urskogsvärden i fem skogsreservat i Kronobergs län. Examensarbete 20 p, Ekologisk botanik, Umeå Universitet.

Faith, D.P., Minchin, P.R. \& Belbin, L. (1987) Compositional dissimilarity as a robust measure of ecological distance. Vegetatio, 69, 57-68. 
615 Foster, D.R., Motzkin, G. \& Slater, B. (1998) Land-use history as long-term broad-scale

616 disturbance: regional forest dynamics in central New England. Ecosystems, 1, 96-119.

617 Foster, D.R. \& Zebryk T.M. (1993) Long-term vegetation dynamics and disturbance history

618 of a Tsuga-dominated forest in New England. Ecology 74, 982-998.

619 Fritzböger, B. (1992) Danske skove 1500-1800. PhD thesis, Odense University, Denmark.

620 Gaillard. M.-J. (1984) A palaeohydrological study of Krageholmssjön (Scania, South

621 Sweden). Regional vegetation history and water-level changes. LUNDQUA Report 25.

622 Gaillard, M.-J. (2007) Archaeological Applications - past human impact inferred from pollen

623 data. "Encyclopedia of Quaternary Science" (ed S.A. Elias), pp. 2570-2595. Elsevier,

$624 \quad$ Amsterdam.

625 Gärdenfors, U. (2005) Red-listed species in Sweden 2005. ArtDatabanken, SLU, Uppsala.

626 Giesecke, T. (2004) The Holocene Spread of Spruce in Scandinavia. PhD thesis, Acta

627 Universitatis Upsaliensis, Uppsala.

628 Giesecke, T. \& Bennett, K.D. (2004) The Holocene spread of Picea abies (L.) Karst. in

629 Fennoscandia and adjacent areas. Journal of Biogeography, 31, 1523-1548.

630 Götmark, F. (2007) Careful partial harvesting in conservation stands and retention of large

631 oaks favor oak regeneration. Biological Conservation, 140, 349-358.

632 Götmark, F., Berglund, Å. \& Wiklander, K. (2005) Browsing damage on broadleaved trees in

633 seminatural temperate forest in Sweden, with a focus on oak regeneration. Scandinavian

634 Journal of Forest Research, 20, 223-234.

635 Götmark, F., Fridman, J. \& Kempe, G. (2009) Education and advice contribute to increased

636 density of broadleaved conservation trees, but not saplings, in young forest in Sweden.

637 Journal of Environmental Management, 90, 1081-1088. 
638 Götmark, F., Fridman, J., Kempe, G. \& Norden, B. (2005) Broadleaved tree species in conifer-dominated forestry: Regeneration and limitation of saplings in southern Sweden. Forest Ecology and Management, 214, 142-157.

641 Greisman, A. and Gaillard M.-J. (2009). The role of climate variability and fire in early and mid Holocene forest dynamics of southern Sweden. Journal of Quaternary Science, 24,

Gustafsson, L. \& Ahlén, I. (eds) (1996) National Atlas of Sweden - Geography of Plants and Animals. SNA Publishing, Stockholm.

Hammarlund, D., Björck, S., Buchardt, B., Israelson, C. \& Thomsen, C.T. (2003) Rapid hydrological changes during the Holocene revealed by stable isotope records of lacustrine

Hannon, G., Bradshaw, R.H.W. \& Emborg, J. (2000) 6000 years of forest dynamics in Suserup Skov, a semi-natural Danish woodland. Global Ecology and Biogeography,

Hedin, J. (2003) Metapopulation ecology of Osmoderma eremita - dispersal, habitat quality and habitat history. PhD thesis, Lund University, Sweden. patchy cultural landscapes and signals of anthropogenic landscape disturbance in the pollen record: A simulation approach. Review of Palaeobotany and Palynology, 153, $245-258$. 
Hellman, S., Gaillard, M.-J., Bunting, J. \& Mazier, F. (2009b) Relevant source area of pollen in past cultural landscapes - a simulation approach. Review of Palaeobotany and Palynology 153, 259-271.

Hesselman, H. \& Schotte, G. (1906) Granen vid sin sydvästgräns i Sverige. Meddelanden från Statens skogsförsöksanstalt, H. 3, 1-52. Stockholm.

Hultberg, T., Brunet, J., Broström, A. \& Lindbladh, M. (2010) Forest in a cultural landscape the vegetation history of Torup in southernmost Sweden. Ecological Bulletins, 53, 000000.

Huntley, B., Bartlein, P.J. \& Prentice, I.C. (1989) Climatic control of the distribution and abundance of beech (Fagus L.) in Europe and North America. Journal of Biogeography, $16,551-560$.

Huntley, B. \& Webb III., T. (1989) Migration: species' response to climatic variations caused by changes in the earth's orbit. Journal of Biogeography, 16, 5-19.

Iversen, J. (1973) The development of Denmark's Nature since the Last Glacial. Danmarks Geologiske Undersögelse, 7C, 1-126.

Jacobson, G.L. \& Bradshaw, R.H.W. (1981) The selection of sites for paleovegetational studies. Quaternary Research, 1, 80-96.

Jonsell M., Weslien J. \& Ehnström B. (1998) Substrate requirements of red-listed saproxylic invertebrates in Sweden. Biodiversity and Conservation, 7, 749-764.

Kardell, L. (2004) Svenskarna och skogen: del 2 : från baggböleri till naturvård. Skogsstyrelsens förlag, Jönköping, Sweden.

Lagerås, P. (2007). The Ecology of Expansion and Abandonment. National Heritage Board, Sweden.

Larsen, J. B., Raulund-Rasmussen, K. \& Callesen, I. (2005) Træartsvalet - de enkelte træarters økologi. DST - Dansk Skovbrugs Tidsskrift, 90, 139-169. 
Lindbladh, M., Niklasson, M. \& Nilsson, S.G. (2003) Long-time record of fire and open canopy in a high biodiversity forest in southeast Sweden. Biological Conservation, 114, $231-243$

Lindbladh, M. \& Bradshaw, R.H.W. (1998) The origin of present forest composition and pattern in southern Sweden. Journal of Biogeography, 25, 463-477.

Lindbladh, M. (1999) The influence of former land-use on vegetation and biodiversity in the boreo-nemoral zone of Sweden. Ecography, 22, 485-498.

Lindbladh, M., Brunet, J., Hannon, G., Niklasson, M., Eliasson, P., Eriksson, G. \& Ekstrand, A. (2007) Forest history as a basis for ecosystem restoration - a multi-disciplinary casestudy in a south Swedish temperate landscape. Restoration Ecology, 15, 284-295.

Lindbladh, M., Niklasson, M., Karlsson, M., Björkman, L. \& Churski, M. (2008) Close anthropogenic control of Fagus establishment and expansion in a Swedish protected landscape - implications for forest history and conservation. Journal of Biogeography, 35, 682-697.

Lindenmayer, D. B. \& Franklin, J. F. (2002) Conserving forest biodiversity: a comprehensive multiscaled approach. Island Press, Washington, D.C..

Madsen, P. \& Löf, M. (2005) Reforestation in southern Scandinavia using direct seeding of oak (Quercus robur L.). Forestry, 78, 55-64.

McCune, B. \& Mefford, M.J. (1999) Multivariate Analysis of Ecological data, Version 4. MjM Software Design. Gleneden Beach, Oregon, USA.

Miller, P.A., Giesecke, T., Hickler, T., Bradshaw, R.H.W, Smith, B., Seppä, H., Valdes, P.J. \& Sykes, M.T. (2008) Exploring climatic and biotic controls on Holocene vegetation change in Fennoscandia. Journal of Ecology 96, 247-259. 
Moberg, A., Sonechkin, D.M., Holmgren, K., Datsenko, N.M. \& Karlén, W. (2005) Highly variable Northern Hemisphere temperatures reconstructed from low- and highresolution proxy data. Nature 433, 613-617.

Molinari, C. (2002) 2500 years of Forest Dynamics at Söndre Skog, a semi-natural Forest on Hallands Väderö island, Southern Sweden. Ms thesis, Turin University, Italy.

Niklasson, M. \& Nilsson S.G. (2005) Skogsdynamik och arters bevarande. Studentlitteratur, Sverige.

Niklasson, M. \& Drakenberg, B. (2001) A 600-year tree-ring fire history from Norra Kvill National Park, southern Sweden: implication for conservation strategies in the hemiboreal zone. Biological Conservation, 101, 63-71.

Niklasson, M., Lindbladh, M. \& Björkman, L. (2002) A long-term record of Quercus decline, logging and fire history in a southern Swedish Fagus-Picea forest. Journal of Vegetation Science, 13, 765-774.

Nilsson P., Kempe G., Toet, H. \& Petersson, H. (2008) Skogsdata 2008: aktuella uppgifter om de svenska skogarna från Riksskogstaxeringen : Tema: Skogens roll för klimatet Skogsdata vol 2008.

Nilsson, S.G., Niklasson, M., Hedin, J., Aronsson. G., Gutowski, J.M., Linder, P., Ljungberg, H., Mikusinski, G. \& Ranius, T. (2002) Densities of large living and dead trees in oldgrowth temperate and boreal forests. Forest Ecology and Management, 161, 189-204.

Nilsson, S.G., Niklasson, M., Hedin, J., Eliasson, P. \& Ljungberg, H. (2005) Biodiversity and sustainable forestry in changing landscapes - principles and Southern Sweden as an example. Journal of Sustainable Forestry, 21, 11-43.

Nilsson S.G. (2001) Sydsveriges viktigaste områden för bevarandet av hotade artervedskalbaggar som vägvisare till kärnområdena. Fauna och Flora, 96, 59-70. 
Nilsson, T. (1964) Standard pollen diagramme und C14 datiengen aus dem Ageröds mosse in mittleren schonen. Lund Universitets Arsskrift N.F. 2, 59 (7), 52 p.

Nordén, B., Paltto, H. Götmark, F. \& Wallin, K. (2007) Indicators of biodiversity, what do they indicate? - Lessons for conservation of cryptogams in oak-rich forest. Biological Conservation, 135, 369-379.

Økland, B., Götmark, F. \& Nordén, B. (2008) Oak woodland restoration: testing the effects on biodiversity of mycetophilids in southern Sweden. Biodiversity and Conservation, 17, 2599-2616.

Osbeck, P. (1996) Djur och natur i södra Halland under 1700-talet. Bokförlaget Spektra, Halmstad.

Oswald, W.W., Faison, E.K., Foster, D.R., Doughty, E.D., Hall, B.H. \& Hansen, B.C. (2008). Post-glacial changes in spatial patterns of vegetation across southern New England. Journal of Biogeography, 34, 900-913.

Pearson, R.G. \& Dawson, T.P. (2003) Predicting the impacts of climate change on the distribution of species: are bioclimate envelope models useful? Global Ecology and Biogeography, 12, 361-371.

Quinn, G.P. \& Keough, M.J. (2002) Experimental Design and Data Analysis for Biologists. Cambridge University Press, Cambridge.

Ranius, T. (2000) Population biology and conservation of beetles and pseudoscorpions associated with hollow oaks. PhD thesis, Lund University, Sweden.

Ranius, T., Aguado, L.O., Antonsson, K., Audisio, P., Ballerio, A., Carpaneto, G.M., Chobot, K., Gjurašin, B., Hanssen, O., Huijbregts, H., Lakatos, F., Martin, O., Neculiseanu, Z., Nikitsky, N.B., Paill, W., Pirnat, A., Rizun, V., Ruicănescu, A., Stegner, J., Süda, I., Szwałko, P., Tamutis, V., Telnov, D., Tsinkevich, V., Versteirt, V., Vignon, V., Vögeli, 

Europe. Animal Biodiversity and Conservation, 28, 1-44.

Ranius, T., Eliasson, P. \& Johansson, P. (2008) Large-scale occurrence patterns of red-listed lichens and fungi on old oaks are influenced both by current and historical habitat density. Biodiversity and Conservation, 17, 2371-2381.

Ranius, T. \& Hedin, J. (2004) Hermit beetle (Osmoderma eremita) in a fragmented landscape: predicting occupancy patterns. Species conservation and management: case studies (eds H.R. Akçakaya, M.A. Burgman, O. Kindvall, C.C. Wood, P. Sjögren-Gulve, J.S. Hatfield \& M.A. McCarthy), pp. 162-170. Oxford Univ. Press, New York.

Ranius, T. \& Jansson, N. (2000) The influence of forest regrowth, original canopy cover and tree size on saproxylic beetles associated with old oaks. Biological Conservation, 95, $85-94$.

Regnell, J. (1989) Vegetation and land-use history during 6000 years. Palaeoecology of the cultural landscape at two lake sites in southern Skåne, Sweden. Lundqua thesis, Volume 27. Lund University.

Rasmussen, P. (2005) Mid- to late-Holocene land-use change and lake development at Dallund Sø, vegetation and landuse history inferred from pollen data. The Holocene, 15, $1116-1129$.

Seppä, H., Alenius. T., Bradshaw, R.H.W., Giesecke, T., Heikkilä, M. \& Muukkonen, P. (2009) Invasion of Norway spruce (Picea abies) and the rise of the boreal ecosystem in Fennoscandia. Journal of Ecology, 97, 629-640.

Seppä, H., Hammarlund, D. \& Antonsson, K. (2005) Low-frequency and high-frequency changes in temperature and effective humidity during the Holocene in south-central Sweden: implications for atmospheric and oceanic forcings of climate. Climate Dynamics, 25, 285-297. 
Sugita, S. (1994) Pollen representation of vegetation in quaternary sediments: Theory and method in patchy vegetation. Journal of Ecology, 82, 881-897.

Sugita, S. (2007) Theory of quantitative reconstruction of vegetation. I. Pollen from large sites REVEALS regional vegetation. Holocene 17, 229-241.

Sykes, M.T., Prentice, I.C. \& Cramer, W. (1996) A bioclimatic model for the potential distributions of north European tree species under present and future climates. Journal of Biogeography, 23, 203-233.

Talantire, P.A. (1974) The paleohistory of the Grey Alder (Alnus incana (L.) Moench.) and the Black Alder (Alnus glutinosa (L.) Gaertn.) in Fennoscandia. New Phytologist, 73, $529-546$.

Thelaus, M. (1989) Late Quaternary vegetation history and palaeohydrology of the SandsjönÅrshult area, southwestern Sweden. Lundqua thesis, Volume 26, Lund University.

Tilman, D., May, R.M., Lehman, C.L. \& Nowak, M.A. (1994) Habitat destruction and the extinction debt. Nature, 371, 65-66.

Tyler, M. (2008) British oaks: a concise guide. Crowood Press, Marlborough, UK.

Valdemarsdotter, Å. (2001) En skogshistorisk undersökning från östra Småland Vegetationsutveckling och brandhistorik från Ekenäs i Hornsö-området de senaste 3000 åren. Ms thesis 64. Southern Swedish Forest Research Centre, SLU Alnarp.

Vera, F.W.M. 2000. Grazing Ecology and Forest History. CABI Publishing, Oxon, UK.

Wastenson, L. (ed) (1990) National Atlas of Sweden - The Forests. SNA Publishing, Stockholm. 
807 Table 1. Small hollow sites in Denmark and Sweden used in this study. $\mathrm{C}^{14}$ and AMS refer to

808 dating by conventional radiocarbon and accelerator mass spectrometry techniques.

809

\begin{tabular}{|c|c|c|c|c|c|c|}
\hline ID & Site Name & Reference & Location & $\begin{array}{l}\text { Depositional } \\
\text { Environment }\end{array}$ & Historical land-use & $\begin{array}{c}\text { No. of radiocarbon } \\
\text { dates and time span of } \\
\text { profile }\end{array}$ \\
\hline & Temperate zone & & & & & \\
\hline 1 & Lövenholm & Unpublished & $\begin{array}{c}5644^{\prime} \mathrm{N} 10 \\
49^{\prime} \mathrm{E}\end{array}$ & Small wetland & Not defined & $\begin{array}{c}\text { Not available }(9000 \\
\text { BC- present) }\end{array}$ \\
\hline 2 & Suserup & $\begin{array}{l}\text { Hannon et al.. } \\
\text { (2000) }\end{array}$ & $5522^{\prime} \mathrm{N} 1134^{\prime} \mathrm{E}$ & Wetland $20 \times 30 \mathrm{~m}$ & Not defined & $\begin{array}{l}1 \text { C14 \& } 5 \text { AMS } \\
\text { (4200 BC-present) }\end{array}$ \\
\hline 3 & Torup & $\begin{array}{l}\text { Hultberg et al. } \\
\text { (2010) }\end{array}$ & $\begin{array}{l}5556 ' \mathrm{~N} \\
1321 \mathrm{E}\end{array}$ & Wetland 10x10m & Not defined & $\begin{array}{c}6 \text { AMS (3700 BC- } \\
\text { present) }\end{array}$ \\
\hline 4 & Vasahus & $\begin{array}{c}\text { Lindbladh et al. } \\
\text { (2007) }\end{array}$ & $5554^{\prime} \mathrm{N} 1338^{\prime} \mathrm{E}$ & Peat bog $25 \times 40 \mathrm{~m}$ & Outland & $\begin{array}{c}\text { 4 C14 (1310 BC- } \\
\text { present) }\end{array}$ \\
\hline 5 & Kyllingahus & $\begin{array}{c}\text { Lindbladh et al.. } \\
\text { (2007) }\end{array}$ & 55 53'N 13 39'E & Peat bog $15 \times 50 \mathrm{~m}$ & Infield & $\begin{array}{c}5 \text { AMS (4100 BC- } \\
\text { present) }\end{array}$ \\
\hline 6 & Häggenäs & $\begin{array}{c}\text { Lindbladh et al.. } \\
\text { (2007) }\end{array}$ & 55 53'N 13 36'E & Wetland $10 \times 100 \mathrm{~m}$ & Infield & $\begin{array}{c}5 \text { AMS (350 AD- } \\
\text { present) }\end{array}$ \\
\hline 7 & Hälledammen & Molinari (2002) & $\begin{array}{l}5661^{\prime} \mathrm{N} \\
1301^{\prime} \mathrm{E}\end{array}$ & Pond $50 \times 50 \mathrm{~m}$ & Outland & $\begin{array}{c}4 \text { AMS (850 BC-AD } \\
1750)\end{array}$ \\
\hline 8 & Eriksberg & $\begin{array}{c}\text { Hannon } \\
\text { (unpublished) }\end{array}$ & $5611^{\prime} \mathrm{N} 1500^{\prime} \mathrm{E}$ & Wetland $10 \times 10 \mathrm{~m}$ & Not defined & $\begin{array}{c}4 \text { AMS (5200 BC- } \\
\text { present) }\end{array}$ \\
\hline 9 & Kalvaberget & $\begin{array}{c}\text { Lindbladh et al.. } \\
\text { (2008) }\end{array}$ & $5648^{\prime} \mathrm{N} 12$ 54'E & Wetland $150 \times 25 \mathrm{~m}$ & Not defined & $\begin{array}{c}8 \text { AMS (600 BC- } \\
\text { present) }\end{array}$ \\
\hline 10 & Holkåsen & $\begin{array}{c}\text { Lindbladh et al. } \\
\text { (2008) }\end{array}$ & $5648^{\prime} \mathrm{N} 12$ 54'E & $\begin{array}{l}\text { Wetland in } \\
\text { depression } \\
50 \times 10 \mathrm{~m}\end{array}$ & Outland & $\begin{array}{c}6 \text { C14 (1500 BC- } \\
\text { present) }\end{array}$ \\
\hline 11 & Trälhultet & $\begin{array}{c}\text { Lindbladh } \text { et al.. } \\
\end{array}$ & $5648^{\prime} \mathrm{N} 12$ 54'E & Wetland 200x40m & Outland & $\begin{array}{c}4 \text { AMS (1300 BC- } \\
\text { present) }\end{array}$ \\
\hline
\end{tabular}




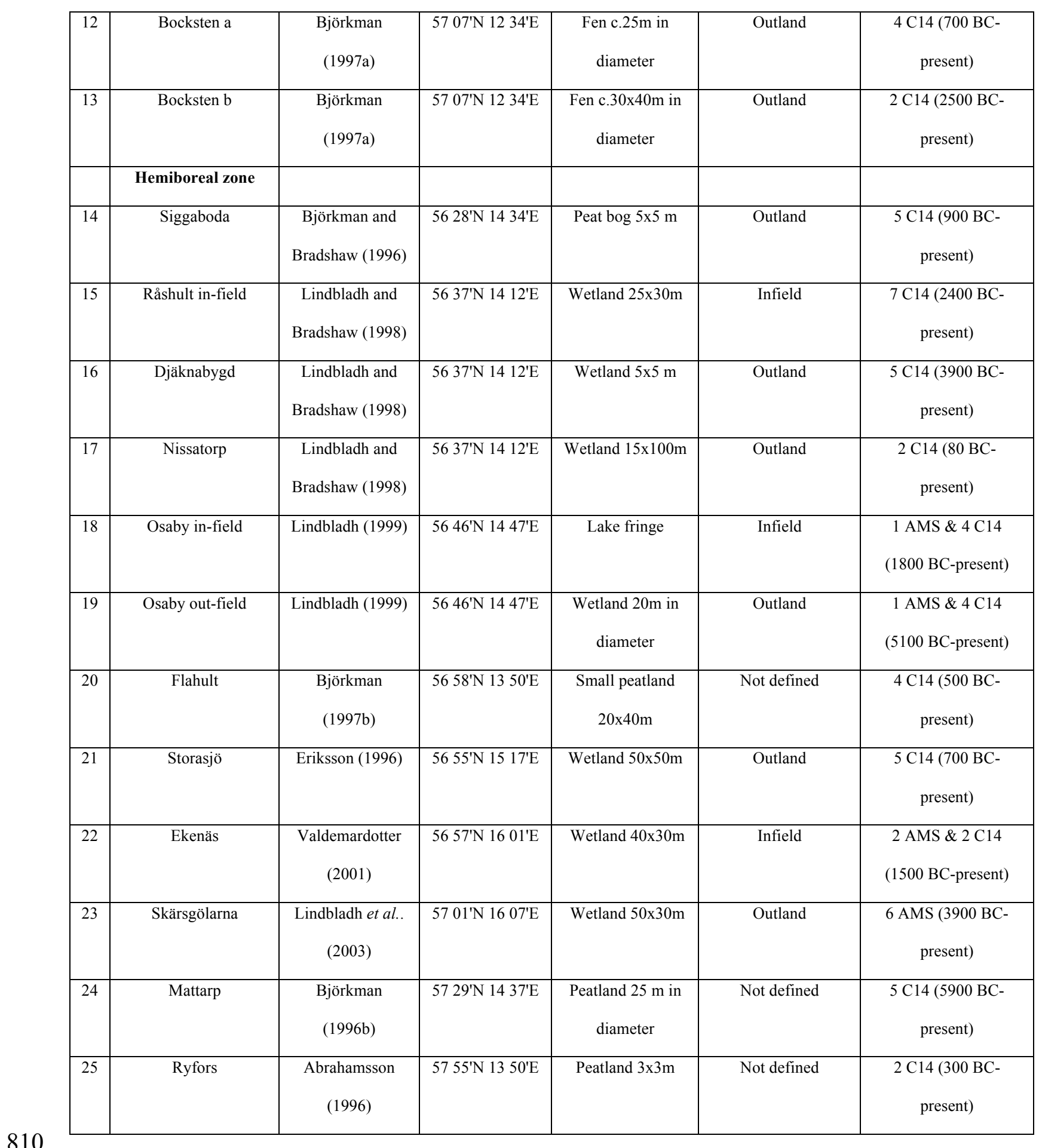

811 
815 Table 2. Results from Spearman's partial correlation of the relationship during the last 1800

816 years between Quercus, other taxa and the anthropogenic indicators.

817

\begin{tabular}{|c|c|c|c|c|c|}
\hline \multicolumn{3}{|l|}{ Temperate sites } & \multicolumn{3}{|l|}{ Hemiboreal sites } \\
\hline & $\mathbf{r}^{2}$ & p-value & & $\mathbf{r}^{2}$ & p-value \\
\hline \multicolumn{3}{|l|}{ Positive correlation } & \multicolumn{3}{|l|}{ Positive correlation } \\
\hline Tilia & 0.44 & $<<.0001$ & Corylus & 0.58 & $<.0001$ \\
\hline Corylus & 0.32 & $<.0001$ & Tilia & 0.55 & $<.0001$ \\
\hline Alnus & 0.22 & $<.0001$ & Alnus & 0.50 & $<.0001$ \\
\hline \multicolumn{3}{|l|}{ Negative correlation } & \multicolumn{3}{|l|}{ Negative correlation } \\
\hline Cerealia & -0.47 & $<<.0001$ & Pinus & -0.54 & $<.0001$ \\
\hline Picea & -0.41 & $<<.0001$ & Picea & -0.52 & $<.0001$ \\
\hline Fagus & -0.35 & $<.0001$ & Anthropogenic indicators & -0.26 & 0.0002 \\
\hline Pinus & -0.28 & $<.0001$ & Betula & -0.20 & 0.004 \\
\hline Betula & -0.26 & $<.0001$ & Calluna & -0.18 & 0.01 \\
\hline Anthropogenic indicators & -0.24 & $<.0001$ & Cerealia & -0.17 & 0.015 \\
\hline Poaceae & -0.17 & 0.0003 & Poaceae & -0.16 & 0.026 \\
\hline \multirow[t]{3}{*}{ Calluna } & -0.13 & 0.0044 & & & \\
\hline & & & \multicolumn{3}{|l|}{ No correlation } \\
\hline & & & Fagus & -0.13 & 0.052 \\
\hline
\end{tabular}

818 


\section{Figure captions}

823

824 Figure 1. Map of southern Scandinavia with the sites used in the study. See Table 1 for the 825 names of the small hollow sites. The regional lake sites include: A. Lake Trummen and Lake Växjösjön, B. Lake Ranviken, C. Lake Kansjön, D. Ageröds Mosse, E. Lake Krageholmssjön, F. Lake Färskesjön.

Figure 2. Past and present distribution of Quercus in southern Sweden, modified from Björse et al. (1996). The modern data are based on forest inventory data and represent percentages of the total growing stock. The data from 2000 and 1000 BP (years Before Present) represent estimated growing stock and are made from a network of 37 regional pollen sites. The maps are from the National Atlas of Sweden - Geography of Plants and Animals (Gustafsson \& Ahlén 1996).

Figure 3. Quercus pollen values from local and regional sites. Panel A shows hemiboreal regional sites: solid line is Lake Trummen (-AD 800) and Lake Växjösjön (AD 600-), dotted line is Lake Ranviken, dashed-dotted is Lake Kansjön. Panel B shows temperate regional sites: solid line is Ageröds mosse, dotted line is Lake Krageholmssjön, dashed-dotted line is Lake Färskesjön. Panel C is mean pollen percentage of Quercus from the temperate and hemiboreal small hollow sites. The lower panel shows the number of small hollow sites included in their respective time periods. Each data point represents a 200-year or 100-year period. As an example: AD 1500 represents AD 1500-1599, i.e. the $16^{\text {th }}$ century. 
845 Figure 4. Mean pollen percentage of all taxa and anthropogenic indicators included in the 846 study from the temperate and hemiboreal sites. Note the different scales on the y-axes. Each 847 data point represents a 200-year or 100-year period. As an example: AD 1500 represents AD $8481500-1599$, i.e. the $16^{\text {th }}$ century. The temperature data is from Moberg et al. (2005),

849 temperature anomalies (low-frequency component AD 133-1925) from the northern

850 hemisphere annual mean temperature 1961-90 average.

851

852 Figure 5. Maps depicting the pollen percentages for selected taxa for five periods: $399-200$ 853 BC, AD 200-299, AD 900-999, AD 1600-1699 and AD 1900-1999. Note that Cerealia and 854 anthropogenic indicators have different classes than the tree taxa.

855

856 Figure 6. Mean pollen percentage of Quercus from infield and outland sites. Each data point 857 represents a 200-year or 100-year period. As an example: AD 1500 represents AD 1500-1599, 858 i.e. the $16^{\text {th }}$ century.

859

860 Figure 7. Ordination axes 1 and 2 from the NMS multivariate analysis (non-metric 861 multidimensional scaling ) with the values for the different taxa.

862

863 Figure 8. Ordination axes 1 and 2 from the NMS multivariate analysis (non-metric

864 multidimensional scaling ) with the values for the sites from the two vegetation zones and the 865 taxa from four periods: AD 200-299, AD 900-999, AD 1600-1699 and AD 1900-1999. 
Please read this form carefully before signing: conditions are changed from time to time and may not be the same as the last time you completed one of these forms

$$
\text { WILEY- }
$$

BLACKWELL

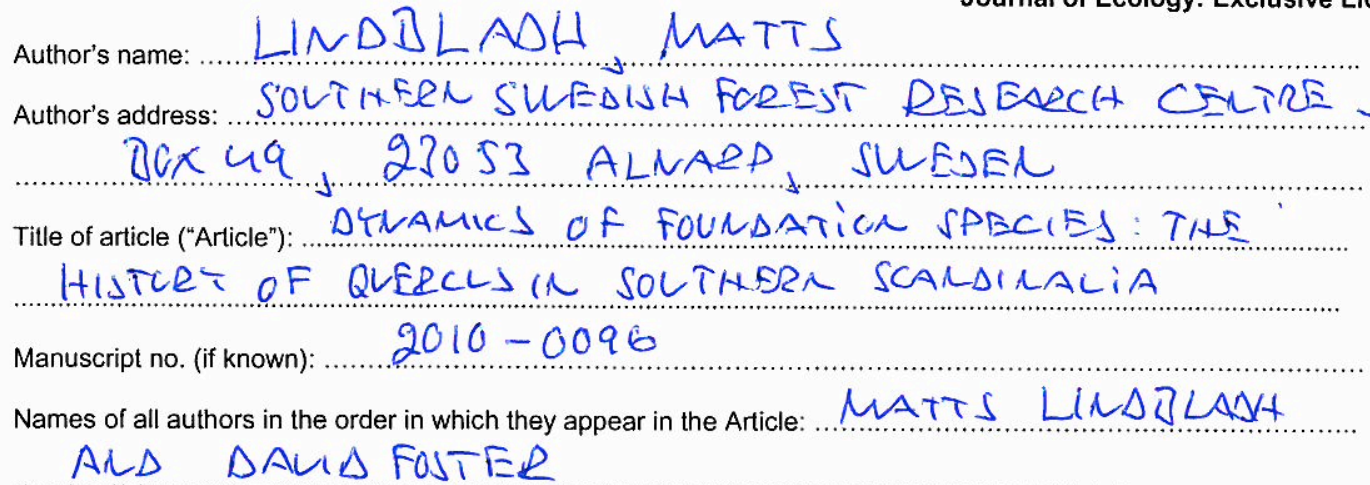

In order for your Article to be distributed as widely as possible in Journal of Ecology (the Journal) you grant Blackwell Publishing Lid (Blackwell Publishing) an exclusive licence to publish the above Article on behalf of the British Ecological Society, including the abstract in printed and electronic form, in all languages, and to administer subsidiary rights agreements with third parties for the full period of copyright and all renewals, extensions, revisions and revivals. The Article is deemed to include all material submitted for publication with the exception of Letters, and includes the text, figures, tables, author contact details and all supplementary material accompanying the Article.

Please read this form carefully, sign at the bottom (if your employer owns copyright in your work, arrange for your employer to sign where marked), and return the ORIGINAL as instructed below as quickly as possible. As author, you remain the copyright owner of the Article, unless copyright is owned by your employer. (US Federal Government authors please note: your Article is in the public domain.)

\section{Your Article will not be published unless an Exclusive Licence Form has been signed and received by Blackwell} Publishing.

Please note: You retain the following rights to re-use the Article, as long as you do not sell or reproduce the Article or any part of it for commercial purposes (i.e. for monetary gain on your own account or on that of a third party, or for indirect financial gain by a commercial entity). These rights apply without needing to seek permission from Blackwell Publishing.

- $\quad$ Prior to acceptance: We ask that as part of the publishing process you acknowledge that the Article has been submitted to the Journal. You will not prejudice acceptance if you use the unpublished Article, in form and content as submitted for publication in the Journal, in the following ways:

$\circ \quad$ sharing print or electronic copies of the Article with colleagues;

- posting an electronic version of the Article on your own personal website, on your employer's website/repository and on free public servers in your subject area.

- After acceptance: Provided that you give appropriate acknowledgement to the Journal, the British Ecological Society, and Blackwell Publishing, and full bibliographic reference for the Article when it is published (see recommended statement below), you may use the accepted version of the Article as originally submitted for publication in the Journal, and updated to include any amendments made after peer review, in the following ways:

- you may share print or electronic copies of the Article with colleagues;

- you may use all or part of the Article and abstract, without revision or modification, in personal compilations or other publications of your own work;

- you may use the Article within your employer's institution or company for educational or research purposes including use in course packs;

- After publication:

- Immediately after publication you may replace the unreviewed version on your own personal website, on your employer's website/repository and on free public servers in your subject area, with the abstract only of the published article

- Electronic versions of the accepted article must include the following statement, adapled as necessary for your Article:

Author Posting. (C) The Authors \{Insert year of publication\}. The full text of this article is published in \{insert journal name $\}$, \{insert volume, issue number and pages\}. It is available online at http://dx.doi.org/ \{insert doi number\} N.B. The full text of your Article will be made freely available 2 years after publication.

- You may also share the PDF of the article with colleagues and use it for educational or research purposes, as described above.

\section{Please note that you are not permitted to post the Blackwell Publishing PDF version of the Article online.}

All requests by third parties to re-use the Article in whole or in part will be handled by Blackwell Publishing. Any permission fees will be retained by the Journal. All requests to adapt substantial parts of the Article in another publication (including publication by Blackwell Publishing) will be subject to your approval (which is deemed to be given if we have not heard from you within 4 weeks of your approval being sought by us writing to you at your last notified address). Please address any queries to permissionsuk@wiley.com

In signing this Agreement: 
1. You hereby warrant that this Article is an original work, has not been published before and is not being considered for publication elsewhere in its final form either in printed or electronic form;

2. You hereby warrant that you have obtained permission from the copyright holder to reproduce in the Article (in all media including print and electronic form) material not owned by you, and that you have acknowledged the source;

3. You hereby warrant that this Article contains no violation of any existing copyright or other third party right or any material of an obscene, indecent, libellous or otherwise unlawful nature and that to the best of your knowledge this Article does not infringe the rights of others;

4. You hereby warrant that in the case of a multi-authored Article you have obtained, in writing, authorization to enter into this Agreement on their behalf and that all co-authors have read and agreed the terms of this Agreement;

5. You warrant that any formula or dosage given is accurate and will not if properly followed injure any person;

6. You will indemnify and keep indemnified the Editors, the British Ecological Society and Blackwell Publishing against all claims and expenses (including legal costs and expenses) arising from any breach of this warranty and the other warranties on your behalf in this Agreement.

By signing this Agreement you agree that Blackwell Publishing may arrange for the Article to be:

- Published in the above Journal, and sold or distributed, on its own, or with other related material;

- Published in multi-contributor book form or other edited compilations by Blackwell Publishing;

- Reproduced and/or distributed (including the abstract) throughout the world in printed, electronic or any other medium whether now known or hereafter devised, in all languages, and to authorize third parties (including Reproduction Rights Organizations) to do the same;

- You agree to Blackwell Publishing using any images from the Article on the cover of the Journal, and in any marketing material.

You authorize Blackwell Publishing to act on your behalf to defend the copyright in the Article if anyone should infringe it, although there is no obligation on Blackwell Publishing to act in this way.

As the Author, copyright in the Article remains in your name (or your employer's name if your employer owns copyright in your work).

Blackwell Publishing undertakes that every copy of the Article published by Blackwell Publishing will include the full bibliographic reference for your Article, together with the copyright statement.

Please tick only one of the boxes below.

BOX A: to be completed if copyright belongs to you

BOX B: to be completed if copyright belongs to your employer (e.g. HMSO, CSIRO)

The copyright holder grants Blackwell Publishing an exclusive licence to publish the Article including the abstract in printed and electronic form, in all languages, and to administer subsidiary rights agreements with third parties for the full period of copyright and all renewals, extensions, revisions and revivals.

Print Name of Copyright holder:

This will be printed on the copyright line on each page of the Article. It is your responsibility to provide the correct information of the copyright holder.

BOX C: to be completed if the Article is in the public domain (e.g. US Federal Government employees) You certify that the Article is in the public domain. No licence to publish is therefore necessary.

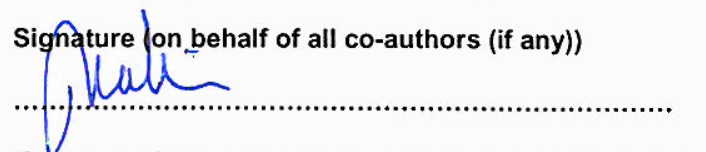

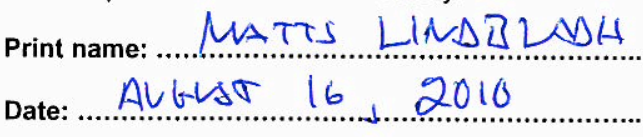

If your employer claims copyright in your work, this form must also be signed below by a person authorized to sign for and on behalf of your employer, as confirmation that your employer accepts the terms of this licence.

Signature (on behalf of the employer of the author (s)) Print name:..

Print name of employer:

Date:

The rights conveyed in this licence will only apply upon acceptance of your Article for publication.

Data Protection: The Publisher may store your name and contact details in electronic format in order to correspond with you about the publication of your Article in the Journal. We would like to contact you from time to time with information about new Blackwell publications and services in your subject area. (For European contributors, this may involve transfer of your personal data outside the European Economic Area.) Please check the following boxes if you are happy to be contacted in this way:

(conventional mailing)

(via e-mail)

A completed and signed form should be scanned and an electronic copy uploaded to Scholar One Manuscripts at the same time as the final revision of your manuscript. If this is not possible, the hard copy of the ORIGINAL should be posted to the Production Editor, Journal of Ecology, Wiley-Blackwell, 101 George Street, Edinburgh, EH2 3ES, UK. 
